\title{
UTILIZATION OF MACROPHYTE BIOFILTER IN EFFLUENT FROM AQUACULTURE: I. FLOATING PLANT
}

\author{
SIPAÚBA-TAVARES, L. H., ${ }^{1}$ FÁVERO, E. G. P. ${ }^{1}$ and BRAGA, F. M. S. ${ }^{2}$ \\ ${ }^{1}$ Centro de Aqüicultura, Unesp, Via de Acesso Prof. Paulo Donato Castellane s/n, CEP 14870-000, \\ Jaboticabal, SP, Brazil, e-mail: sipauba@caunesp.unesp.br \\ ${ }^{2}$ Depto de Zoologia, Unesp, Av. 24 A, 1515, CEP 13500-000, Rio Claro, SP, Brazil, \\ e-mail: fmsbraga@ms.rc.unesp.br \\ Correspondence to: Lúcia Helena Sipaúba Tavares, Centro de Aqüicultura, Unesp, \\ Via de Acesso Prof. Paulo Donato Castellane s/n, CEP 14870-000, \\ Jaboticabal, SP, Brazil, e-mail: sipauba@caunesp.unesp.br \\ Received May 21, 2001 - Accepted October 10, 2001 - Distributed November 30, 2002
}

(With 1 figure)

\begin{abstract}
The objective of this work was to manufacture a low-cost biofilter, made of floating macrophyte (Eichhornia crassipes). Limnological studies were conducted 7 days after the macrophytes were placed in the biofilter, and continued over a period of 30 consecutive days. During rainy and dry seasons, and high production period, samples were taken three times a week. The lowest levels of nitrogen compounds were observed in the July/August period, which corresponded to lower fish production and low supply rattion in the culture ponds. During the experimental period, $\mathrm{pH}$ values ranged from acid to alkaline and did not oscillate with higher average values during April/May. Alkalinity and bicarbonate dominance in the medium were directly affected by $\mathrm{pH}$. With respect to associated micro-fauna, among phyto-plankton Chlorophyta was the dominant group and among zooplankton, Rotifera. It is recommended that during production peaks, the aquatic plants should be replaced by small buds every 10 days.
\end{abstract}

Key words: biofilter, water hyacinth, impact, Eichhornia crassipes, aquaculture.

\section{RESUMO}

\section{Utilização de biofiltros de macrófitas em efluentes de aqüicultura: I. Planta flutuante}

O objetivo deste trabalho foi confeccionar um biofiltro de baixo custo constituído por macrófita flutuante (Eichhornia crassipes). Os estudos limnológicos foram realizados 7 dias depois de colocadas as macrófitas no biofiltro, durante um período de 30 dias consecutivos, com amostragens 3 vezes por semana nas épocas de chuva, seca e de alta produção de organismos cultivados. Quanto aos compostos nitrogenados, as menores concentrações foram observadas no período de jul./ago., correspondendo à época de baixa produção de peixes e baixa adição de alimento nos tanques e viveiros de cultivo. $\mathrm{O}$ pH manteve-se ligeiramente ácido a alcalino ao longo do período experimental, não apresentando oscilações com os maiores valores médios no período de abr./mai. Os valores de $\mathrm{pH}$ influenciaram diretamente a alcalinidade e a dominância de bicarbonato no meio. Quanto à microfauna associada, entre os fitoplanctônicos as Chlorophyta foram o grupo dominante e entre os zooplanctônicos foram os Rotifera. Recomenda-se, no período de alta produção, substituição das plantas aquáticas por brotos bem pequenos a cada 10 dias.

Palavras-chave: biofiltro, aguapé, impacto, Eichhornia crassipes, aqüicultura. 


\section{INTRODUCTION}

For the past few years, uncontrolled aquaculture has increased causing negative impact on the environment. In general, waters from these systems empty directly into rivers and streams, without previous treatment.

Currently, a large variety of biofilters is commercially available designed to minimize the impacts caused by aquaculture. However, they are expensive and difficult to set up.

Therefore, the objective of this work was to construct a low-cost biofilter, made of floating macrophyte (Eichhornia crassipes). These aquatic plants are highly capable of removing nutrients used in their growth and, in the process, they partially reduce the load resulting from the culture of aquatic organism, thus improving water quality.

One of the main impacts associated with aquaculture is the increase of solids, which are rich in organic matter, and nitrogen and phosphate compounds resulting from leftover food and/or organism metabolism (Silva \& Anderson, 1995).

Improvement of water quality in culture ponds can be achieved by biofilters. Their use may assure sustainable development of aquaculture activity, over a broad regional range with the many influences created by different climates, edaphic factors, aquatic organism culture varies regionally of climate, edaphic factors, and population habits. The management ultimately envisioned should be integrated so that residues originating from these aquaculture systems be reused in agriculture, wetlands, hydroponic culture, ${ }_{2}$ or biofilters.

From the ecological viewpoint, the impact and local changes caused by aquaculture may be minimized if adequate limnological management is used. This requires evaluating the probable factors acting directly on the system, so as to guarantee high biomass without damaging the environment.

\section{MATERIALS AND METHODS}

\section{Study area and limnological characteristics}

The work was conducted at Centro de Aqüicultura $\left(21^{\circ} 15^{\prime} 22^{\prime}, \mathrm{S}\right.$ and $\left.48^{\circ} 18^{\prime} 58^{\prime}, \mathrm{W}\right)$, UNESP, Jaboticabal campus, SP, Brazil.

Limnological studies were carried out after the macrophytes were in the biofilter for 7 days, for 30 consecutive days. Samples were collected 3 times a week during the rainy the season (April/ May), dry season (July/August), and fish production peak (November/December). Five sampling points were evaluated, at 3 points inside the biofilter $\left(\mathrm{P}_{2}\right.$, $\mathrm{P}_{3}$ and $\left.\mathrm{P}_{4}\right)$ and 2 outside, and the water inlet $\left(\mathrm{P}_{1}\right)$ and outlet $\left(\mathrm{P}_{5}\right)$. Samples were collected in the morning, between 8:30 and 10:30.

The biofilter consisted of two 5,000 L-water tanks $\left(\mathrm{P}_{2}\right.$ and $\left.\mathrm{P}_{4}\right)$ connected by a $5 \mathrm{~m}$-canal $\left(\mathrm{P}_{3}\right)$. Plants were distributed over the water surface, an area of $7.5 \times 1.13 \mathrm{~m}$ and $0.4 \mathrm{~m}$ deep, with an approximate $3.4 \mathrm{~m}^{3}$ volume.

Limnological characteristics are shown in Table 1 .

\section{Biological data}

The growth of Eichhornia crassipes biomass was determined by monitoring foliar height and width, as well as rhizome total length over the period. The measurements were performed on the same marked plants, which were randomly chosen at the beginning of the experiment.

TABLE 1

Limnological characteristics analysed.

\begin{tabular}{|l|l|}
\hline Limnological characteristics & Methods \\
\hline Temperature, $\mathrm{pH}$, Dissolved Oxygen, Conductivity & Horiba U 10 \\
\hline Alkalinity and Inorganic Carbon & Mackereth et al. (1978) \\
\hline Ammonia & Koroleff (1976) \\
\hline Nitrite, Nitrate, Total Phosphorus and Orthophosphate & Golterman et al. (1978) \\
\hline Residence Time & Time by Volume \\
\hline Chlorophyll $a$ & Nush (1980) \\
\hline
\end{tabular}


Dry and wet weights were recorded at the beginning and end of the experiment. About three plants were collected at each sampling point inside the biofilter $\left(\mathrm{P}_{2}, \mathrm{P}_{3}\right.$ and $\left.\mathrm{P}_{4}\right)$, dried at $60^{\circ} \mathrm{C}$, and weighed to constant weight.

Total-N and total-P for E. crassipes biomass were determined according to sulfide digestion (AOAC, 1970) and phosphovanadomolibidate acid (Sarruge \& Haag, 1974), respectively. Plants were sampled before being placed in the biofilter and after the experiment ended to determine incorporated amount.

To analyze associated micro-fauna, at the end of each experimental period, a single plant was washed and concentrated in $25 \mu \mathrm{m}$ mesh-net, fixated with $4 \%$ formalin; after that individuals were identified and counted.

\section{Data analysis}

Total-P and total-N data were analyzed by a Three-Way Anova without replication (Factorial Anova) (Sokal \& Rohlf, 1981). Final biomass was analyzed by a Two-Way Anova with single observation (Fowler et al., 1998).

Limnological data, such as $\mathrm{pH}$, conductivity, chlorophyll $a$, nitrite, ammonia, and total phosphorus and orthophosphate were analyzed by a non-parametric statistical test, Friedman proof for great $\mathrm{N}$ (samples) and $\mathrm{K}$ (months) values, which considers related samples, and for phyto-plankton and zooplankton variations associated to macrophytes (Siegel, 1975).

Significance level adopted for the statistical test results was 0.05 .

\section{RESULTS}

\section{Limnological characteristics}

Alkalinity, chlorophyll $a$, temperature, conductivity, and bicarbonate presented the highest average values over the high production period (November/December). On the other hand, nitrate, ammonia, and total and free $\mathrm{CO}_{2}$ displayed the highest average values in April/May, the period when the tanks are emptied to collect fishes, shrimps, and frogs, resulting in high discharge of these compounds in the water. Only $\mathrm{pH}$ and dissolved oxygen values were higher during July/ August, the low production period. Therefore, less residue decomposition was caused by the system and there was a low water demand for ponds and tanks, which resulted in higher water availability (Table 2).

In April/May, $\mathrm{pH}$ varied $(\mathrm{p}<0.001)$ with lower average value in $\mathrm{P} 1$.

Among nitrogen compounds, nitrate and ammonia were dominant and there was a slight increase in nitrate and decrease in nitrite and ammonia when passing through the biofilter. Similar to nitrite, ammonia in July/August and November/December also presented lower concentrations, which did not occur with nitrate. Probably, the constant water flow caused oxygen levels to increase and promoted a nitrifying process in the system (Table 2).

Decreasing ammonia levels during the last experimental period (from the $12^{\text {th }}$ day on) were associated with rainfall during the period. Ammonia and nitrite concentrations were below toxic levels, perhaps because the bacteria on the macrophyte roots may have brought about oxidation of these compounds (Table 2).

Nitrite varied among the biofilter sampling points, with the lowest and highest average values $(\mathrm{p}<0.05)$ found over the April/May and November/December periods, respectively. Ammonia levels varied during April/May ( $\mathrm{p}<$ 0.01) with the lowest values in P5.

Orthophosphate presented similar concentrations in the three periods and total phosphorus levels were reduced over the last experimental period (Table 2).

In general, temperatures did not change significantly over the experimental periods, varying between 20.3 and $25.5^{\circ} \mathrm{C}$ in April/May, 19.3 and $21.2^{\circ} \mathrm{C}$ in July/August, and 24.1 and $27.7^{\circ} \mathrm{C}$ in November/December. Temperature never fell below $19^{\circ} \mathrm{C}$. Temperature values were moderate, a characteristic of the season during which the experiments were conducted (Table 2).

Excessive organic and inorganic matter from the culture systems contributed to high medium conductivity, generally above $100 \mu \mathrm{S} . \mathrm{cm}^{-1}$. It varied from 98 to $122 ; 102$ to 109 , and 105 to $130 \mu \mathrm{S} . \mathrm{cm}^{-1}$ during April/May, July/August and November/ December, respectively. In the biofilter, a slight decrease occurred in conductivity average values (Table 2).

In general, water in the biofilter was oxygenated and values varied from 3.7 to $7.7,6.1$ 
to 8.2 , and 3.4 to $4.1 \mathrm{mg} / \mathrm{L}$ over the three periods, respectively. Water oxygenation was influenced by residence time, with an average value of 28 minutes and 8 seconds over the periods (Table 2).

Throughout the experiment, $\mathrm{pH}$ was slightly acid to alkaline and did not vary much; the highest average values were measured during April/May. The $\mathrm{pH}$ values directly influenced alkalinity and bicarbonate dominance in the medium. Free $\mathrm{CO}_{2}$ decreased over the period. This behavior is important, since it affects the bacteria population contained in the biofilter and lowers system efficiency (Table 2).

Alkalinity varied over the experimental period, with the lowest values found over July/ August and directly associated with the $\mathrm{pH}$. High alkalinity in the biofilter is associated with low free $\mathrm{CO}_{2}$ available in the water, which obviates changes in $\mathrm{pH}$ buffering of the medium. In general, alkalinity and forms of inorganic carbon were reduced in the biofilter (Table 2).

With the exception of $\mathrm{pH}$, nitrite, and ammonia, no other limnological parameters analyzed changed between sampling points over the three studied periods $(\mathrm{p}>0.05)$.

Table 3 shows average values of analyzed parameters, among the sampling points, in the biofilter, experimental periods and, also, summation of runk values $(\mathrm{Rj})$, per period which was used to suggest where change occurs, when indicated by the test.

\section{Biological data}

The highest nutrient removal over July/ August may probably be associated with the highest weight observed, when compared to the first and third periods. The highest growth rate was observed in November/December, probably due to higher temperatures, increased luminosity, and presence of dissolved ions in the water.

Final biomass of $E$. crassipes did not change among the sampling points ( $\mathrm{p}>0.05)$; however, there was a difference between April/May and the other two periods $(\mathrm{p}<0.05)$ (Table 4$)$.

A tendency to higher foliar growth was observed over November/December (high production) with averaged value of $121.33 \mathrm{~cm}$ when compared to April/May $(86.21 \mathrm{~cm})$ and July/ August $(99.89 \mathrm{~cm})$. Probably this fast growth might be associated with a higher nutrient load due to greater food supply during this period and, therefore, a higher intake rate of these elements from the environment (Tables 2 and 4).

There was no significant difference $(\mathrm{p}>0.05)$ in total- $\mathrm{N}$ and total-P values in the macrophytes over the experimental period (Table 5). In general, the studied macrophyte displayed high water content in the biomass with a tendency to increase over the period (Table 3). As for associated microfauna, the planktonic community was represented mainly by phytoplankton, with $99 \%$ of the observed total associated with macrophytes (Fig. 1).

Among the phytoplankton, the Chlorophyta group was the most abundant, representing $85 \%$, $77 \%$, and $92 \%$ of the total observed in April/May, July/August, and November/December periods, respectively. It was followed by these groups: Cyanophyta, Chrysophyta, and Euglenophyta; the three groups together represented approximately $23 \%$ of the total (Fig. 1).

The Chlorophyta group presented the highest number of species, 45 in all, of which the most abundant was the phytoflagellates, totaling 23,690, 27,450 , and 48,048 individuals found for the three periods, respectively. The second largest group was Chrysophyta, with 9 species, and two dominants: Botryococcus sp., with 2,472 and 47,704 individuals in April/May and November/ December, respectively; and Asterionella sp., with 6,600 individuals in July/August. Cyanophyta presented 4 species, and the largest was Microcystis sp. with 7,828, 36,750, and 20,496 individuals in the three periods, respectively. Euglenophyta presented 4 species, and the most abundant was Phacus longicauda, with 824, 900, and 3,864 individuals over April/May, July/August, and November/December, respectively (Fig. 1).

As for zooplankton, there was a dominance of different groups associated with macrophyte: protozoan dominated for the two first periods and insects dominated in the last period, followed by Protozoa (Fig. 1).

The group with the largest number of species was Rotifera, totaling 23, followed by Protozoa, 18; Cladocera, 5; and Copepoda, 4. Insects and Ostracoda were not classified at the species level, and Chaoborus was considered separately. April/ May presented the largest number of individuals, due to the presence of Ilyocryptus spinifer with 302 individuals, Thermocyclops decipiens, 105; 

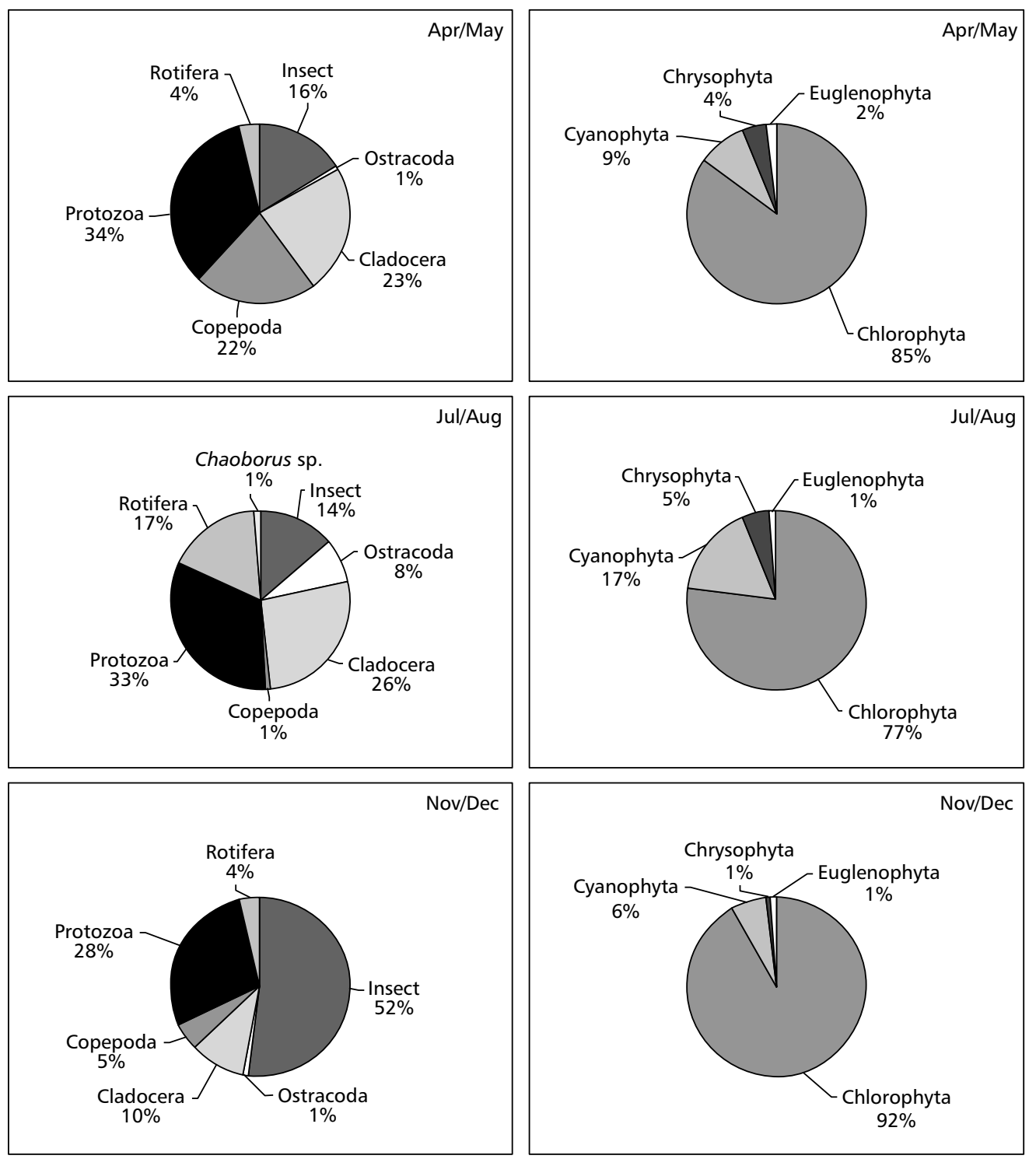

Fig. 1 - Micro-fauna associated with Eichhornia crassipes in the biofilter over the period (April/May; July/August; November/December).

Arcella discoides, 178; Difflugia corona, 169; and insects, 232 (Fig. 1). The Friedman proof did not show significant differences with respect to phytoplankton and zooplankton associated with macrophytes over the period $(\mathrm{p}>0.05)$.

\section{DISCUSSION}

The lowest nitrogen compound levels were detected during the July/August period, which corresponds to low fish production and, therefore, less food addition in the ponds. Nitrate and ammonia were predominant, but in concentrations below toxicity levels for aquatic biota. No effective reduction of nitrogen compounds was observed after the E. crassipes biofilter.

Low concentrations of ammonia during July/ August are associated with high oxygen values in the medium. According to Boyd (2000), higher dissolved oxygen concentrations also increase the ability of nitrifying organisms to oxidize ammonia to nitrate. 


\begin{tabular}{|c|c|c|c|c|c|c|c|c|c|c|c|c|c|c|c|c|}
\hline \multirow{2}{*}{$\begin{array}{l}\text { Limnological } \\
\text { characteristics }\end{array}$} & \multicolumn{5}{|c|}{ Apr/May } & \multicolumn{5}{|c|}{ Jul/Aug } & \multicolumn{5}{|c|}{ Nov/Dec } & \multirow{2}{*}{ Units } \\
\hline & $\mathbf{P}_{1}$ & $\mathbf{P}_{2}$ & $\mathbf{P}_{3}$ & $\mathbf{P}_{4}$ & $\mathbf{P}_{5}$ & $\mathbf{P}_{1}$ & $\mathbf{P}_{2}$ & $\mathbf{P}_{3}$ & $\mathbf{P}_{4}$ & $\mathbf{P}_{5}$ & $\mathbf{P}_{1}$ & $\mathbf{P}_{2}$ & $\mathbf{P}_{3}$ & $\mathbf{P}_{4}$ & $\mathbf{P}_{5}$ & \\
\hline Nitrite & 833.0 & 085.3 & 45.7 & 45.8 & 107.1 & 30.0 & 27.6 & 34.2 & 29.1 & 27.4 & 27.0 & 26.1 & 29.0 & 31.8 & 32.9 & $\mu \mathrm{g} / \mathrm{L}$ \\
\hline Nitrate & 833.0 & 685.3 & 740.9 & 758.4 & 867.0 & 575.9 & 560.0 & 613.1 & 554.4 & 598.6 & 294.0 & 292.0 & 341.0 & 357.8 & 345.3 & $\mu \mathrm{g} / \mathrm{L}$ \\
\hline Ammonia & 316.5 & 11.0 & 420.4 & 349.5 & 252.1 & 39.6 & 37.2 & 53.5 & 45.4 & 43.1 & 245.9 & 260.8 & 252.6 & 247.7 & 253.1 & $\mu \mathrm{g} / \mathrm{L}$ \\
\hline Orthophosphate & 32.8 & 31.9 & 28.5 & 28.8 & 31.5 & 36.9 & 36.1 & 38.5 & 38.5 & 38.6 & 28.6 & 34.6 & 32.5 & 31.3 & 39.4 & $\mu \mathrm{g} / \mathrm{L}$ \\
\hline Total phosphorus & 107.3 & 94.5 & 109.5 & 79.6 & 92.3 & 154.8 & 178.0 & 156.4 & 199.6 & 186.2 & 19.4 & 18.1 & 17.3 & 17.9 & 20.9 & $\mu \mathrm{g} / \mathrm{L}$ \\
\hline Chlorophyll $a$ & 111.1 & 127.6 & 131.8 & 115.4 & 127.8 & 118.8 & 135.5 & 135.5 & 152.6 & 127.7 & 162.2 & 158.8 & 1803 & \begin{tabular}{|l|}
$\mid 179.0$ \\
\end{tabular} & 179.4 & $\mu \mathrm{g} / \mathrm{L}$ \\
\hline Temperature & 22.9 & 22.9 & 22.9 & 22.8 & 22.9 & 20.4 & 20.4 & 20.5 & 20.5 & 20.5 & 26.3 & 26.3 & 26.3 & 26.3 & 26.3 & ${ }^{\circ} \mathrm{C}$ \\
\hline Conductivity & 106.5 & 106.9 & 106.8 & $\mid 107.1$ & 107.0 & 105.8 & 106.1 & 106.4 & 105.5 & 105.3 & 118.1 & 118.1 & 120.5 & 117.3 & 116.1 & $\mu . S / \mathrm{cm}$ \\
\hline Dissolved oxygen & 5.7 & 5.8 & 5.4 & 5.5 & 5.9 & 7.3 & 7.0 & 7.4 & 7.2 & 6.9 & 5.4 & 5.2 & 5.1 & 4.9 & 5.2 & $\mathrm{mg} / \mathrm{L}$ \\
\hline $\mathrm{pH}$ & 6.4 & 6.6 & 6.7 & 6.6 & 6.7 & 7.1 & 7.1 & 7.1 & 7.2 & 7.1 & 7.0 & 7.1 & 7.0 & 7.1 & 7.0 & \\
\hline Total alkalinity & 104.3 & 101.0 & 101.3 & 100.1 & 103.0 & 92.1 & 89.1 & 86.3 & 91.2 & 87.5 & 120.8 & 116.7 & 115.2 & 110.2 & 117.1 & $\mathrm{mg} / \mathrm{L}$ \\
\hline Bicarbonate & 144.7 & 139.9 & 139.4 & 138.3 & 141.2 & 127.5 & 123.3 & 119.5 & 126.2 & 121.2 & 167.2 & 161.3 & 159.5 & 162.3 & 162.1 & $\mathrm{mg} / \mathrm{L}$ \\
\hline Free $\mathrm{CO}_{2}$ & 91.7 & 58.7 & 52.4 & 64.3 & 52.8 & 16.9 & 14.4 & 14.7 & 13.5 & 14.3 & 24.7 & 20.1 & 21.6 & 20.1 & 20.2 & $\mathrm{mg} / \mathrm{L}$ \\
\hline Total $\mathrm{CO}_{2}$ & 192.0 & 181.6 & 181.5 & 182.6 & 182.5 & 144.5 & 137.8 & 134.3 & 139.9 & 135.5 & 192.0 & 181.6 & 181.1 & 182.6 & 182.5 & $\mathrm{mg} / \mathrm{L}$ \\
\hline
\end{tabular}


TABLE 3

Friedman proof results $\left(\mathrm{X}_{r}^{2}\right)$ for limnological data per sampling period. The numerical values outside parenthesis represent the average and values between parenthesis are the sum of runk values $(\mathrm{Rj})$ per sample point $\left(\mathbf{P}_{1} ; \mathbf{P}_{2}\right.$ to $\mathbf{P}_{4} ;$ and $\left.\mathbf{P}_{5}\right)$.

\begin{tabular}{|c|c|c|c|c|c|}
\hline \multirow{2}{*}{ Limnological characteristics } & \multirow{2}{*}{ Periods } & \multicolumn{3}{|c|}{ Sampling points } & \multirow{2}{*}{$\mathbf{X}_{\mathrm{r}}^{2}$} \\
\hline & & $\mathbf{P}_{1}$ & $\mathbf{P}_{2}-\mathbf{P}_{4}$ & $\mathbf{P}_{5}$ & \\
\hline \multirow[t]{4}{*}{$\mathrm{pH}$} & Apr/May & $6.4(15)$ & $7.2(32)$ & $6.7(37)$ & $19 * * *$ \\
\hline & Jul/Agu & $7.2(26)$ & $7.1(24.5)$ & $7.2(33)$ & $0.95 \mathrm{~ns}$ \\
\hline & Nov/Dec & $7.0(25.5)$ & $7.0(24)$ & $7.1(34.5)$ & $4.61 \mathrm{~ns}$ \\
\hline & Apr/May & $105(21)$ & $107(30.5)$ & $107.5(32.5)$ & $5.39 \mathrm{~ns}$ \\
\hline \multirow[t]{3}{*}{ Conductivity } & Jul/Agu & $106(28.5)$ & $106(31)$ & $1059(24.5)$ & $1.54 \mathrm{~ns}$ \\
\hline & Nov/Dec & $119(26.5)$ & $120(33)$ & $117(24.5$ & $2.82 \mathrm{~ns}$ \\
\hline & Apr/May & $110.6(22)$ & $139.5(32)$ & $132.5(30)$ & $4.0 \mathrm{~ns}$ \\
\hline \multirow[t]{3}{*}{ Chlorophyll $a$} & Jul/Agu & $151.7(23.5)$ & $134.3(30)$ & $144.8(30.5)$ & $2.18 \mathrm{~ns}$ \\
\hline & Nov/Dec & $174.6(25.5)$ & $177.9(27)$ & $186.6(31.5)$ & $1.39 \mathrm{~ns}$ \\
\hline & Apr/May & $64.7(25)$ & $44.8(21)$ & $66.2(38)$ & $11.29 \mathrm{~ns}$ \\
\hline \multirow[t]{3}{*}{ Nitrite } & Jul/Agu & $33.4(28.5)$ & $34.6(30.5)$ & $25.8(25)$ & $1.11 \mathrm{~ns}$ \\
\hline & Nov/Dec & $19.7(25.5)$ & $20.5(23)$ & $22.7(35.5)$ & $6.25^{*}$ \\
\hline & Apr/May & $672.3(20.5)$ & $595.9(16.5)$ & $638.1(17)$ & $1.06 \mathrm{~ns}$ \\
\hline \multirow[t]{3}{*}{ Nitrate } & Jul/Agu & $552(27)$ & $563.9(26)$ & $613.1(31)$ & $1.0 \mathrm{~ns}$ \\
\hline & Nov/Dec & 257.7 (24) & 314.7 (27) & 345.7 (33) & $3.0 \mathrm{~ns}$ \\
\hline & Apr/May & $346.5(30)$ & $393.9(36)$ & $279.1(18)$ & $12 * *$ \\
\hline \multirow[t]{3}{*}{ Ammonia } & Jul/Agu & $29.9(24.5)$ & $32(27)$ & 38.7 (32.5) & $2.39 \mathrm{~ns}$ \\
\hline & Nov/Dec & $181.8(23)$ & $194.7(30)$ & $168.7(31)$ & $2.71 \mathrm{~ns}$ \\
\hline & Apr/May & $94.8(31.5)$ & $76(22)$ & $89.7(30.5)$ & $3.89 \mathrm{~ns}$ \\
\hline \multirow[t]{3}{*}{ Total phosphorus } & Jul/Agu & $163.5(26)$ & $152(30)$ & $131.6(28)$ & $0.57 \mathrm{~ns}$ \\
\hline & Nov/Dec & $19.1(26)$ & $17(26.5)$ & $21.6(31.5)$ & $1.32 \mathrm{~ns}$ \\
\hline & Apr/May & $31(28.5)$ & $26.7(27.5)$ & $30(28)$ & $0.04 \mathrm{~ns}$ \\
\hline \multirow[t]{2}{*}{ Orthophosphate } & Jul/Agu & $35.9(26.5)$ & $35.2(24)$ & $41.4(33.5)$ & $3.46 \mathrm{~ns}$ \\
\hline & Nov/Dec & $23.5(23)$ & $29.8(26.5)$ & $33.3(34.5)$ & $4.96 \mathrm{~ns}$ \\
\hline $\mathrm{P}_{0.05 ; 2}=5.99(*)$ & \multicolumn{5}{|c|}{$\mathrm{P}_{0.01 ; 2}=9.21(* *)$} \\
\hline
\end{tabular}

ns - not significant different 
TABLE 4

Two-way variance analysis results, with single observation, for macrophyte final biomass with respect to wet and dry weight.

\begin{tabular}{|c|c|c|c|c|c|c|c|c|}
\hline \multirow{2}{*}{ Variation } & \multicolumn{4}{|c|}{ Dry weight } & \multicolumn{4}{|c|}{ Wet weight } \\
\hline & gl & SS & MS & $\mathbf{F}_{\mathrm{s}}$ & gl & SS & MS & $\mathbf{F}_{\mathrm{s}}$ \\
\hline A month & 2 & 1924.35 & 962.18 & $2.20 \mathrm{~ns}$ & 2 & 144041.53 & 72020.77 & $2.34 \mathrm{~ns}$ \\
\hline B sampling points & 2 & 5.24 & 2.62 & $0.01 \mathrm{~ns}$ & 2 & 32517.96 & 16258.98 & $0.53 \mathrm{~ns}$ \\
\hline Inside & 4 & 1748.93 & 437.23 & & 4 & 123075.16 & 30768.79 & \\
\hline Total & 8 & 3678.52 & 459.82 & & 8 & 299634.65 & 37554.33 & \\
\hline \multicolumn{5}{|c|}{$\mathrm{F}_{0.05(2.4)}=6.94$} & \multicolumn{4}{|c|}{$\mathrm{F}_{0.05(2.4)}=6.94$} \\
\hline
\end{tabular}

On the other hand, the nitrite level was reduced due to constant water flow and the nitrifying process, thus allowing proper functioning of the medium biotic and abiotic processes (Summerfelt et al., 1997). Nutrient levels in the biofilter might have been influenced by the short residence time covered by the present study (circa 28 ' and 8"). According to Boyd (2000), the hydraulic retention time necessary for effective removal of nutrients and other pollutants by aquatic plants is about 1 to 4 days. Low ammonia concentrations in July/August might be associated with low feeding during this period, since much of the nitrogen present in effluents is derived from undigested food in fish excrement, which is transformed by bacteria to ammonia.

TABLE 5

Factorial variance analysis results for macrophyte Total-N and Total-P values.

\begin{tabular}{|c|c|c|c|c|c|c|c|c|}
\hline \multirow{2}{*}{ Variation } & \multicolumn{4}{|c|}{ Total-N } & \multicolumn{4}{|c|}{ Total-P } \\
\hline & gl & SS & MS & $\mathbf{F}_{\mathrm{s}}$ & gl & SS & MS & $\mathbf{F}_{\mathrm{s}}$ \\
\hline A Periods & 2 & 195.92 & 97.96 & & 2 & 18.36 & 9.18 & \\
\hline B Concentration & 1 & 60.87 & 60.86 & & 1 & 9.17 & 9.17 & \\
\hline C Biofilter & 2 & 20.55 & 10.28 & & 2 & 1.15 & 0.58 & \\
\hline $\mathrm{AxB}$ & 4 & 30.43 & 7.61 & $0.72 \mathrm{~ns}$ & 4 & 9.73 & 2.43 & $1.93 \mathrm{~ns}$ \\
\hline $\mathrm{AxC}$ & 4 & 44.49 & 11.12 & $1.05 \mathrm{~ns}$ & 4 & 10.50 & 2.63 & $2.09 \mathrm{~ns}$ \\
\hline $\mathrm{BxC}$ & 2 & 10.23 & 5.12 & $0.48 \mathrm{~ns}$ & 2 & 0.67 & 0.34 & $0.27 \mathrm{~ns}$ \\
\hline $\mathrm{AxBxC}$ & 4 & 42.42 & 10.61 & & 4 & 5.05 & 1.26 & \\
\hline $\mathrm{F}_{0.05(4.4)}=6.39$ & & $\mathrm{~F}_{0.05}$ & $=6.94$ & & & & & \\
\hline
\end{tabular}


The presence of phosphorus and orthophosphate over the experimental period and the increase observed after biofiltering, might be associated with the presence of nitrate, which functions as an electron receptor for phosphorus and accumulates this compound in the system in which excess can be stored by the bacteria as polyphosphate (Barak \& Rijin, 2000).

Low concentration of orthophosphate in effluent might be associated with phosphorus absorption by soil. According to Giri \& Boyd (2000), most of the phosphorus from feed and fish excrement is absorbed by soil, with less than $5 \%$ of the applied phosphorus remaining in the water column.

An effective nutrient reduction was not observed, over the experimental period, except for ammonia during July/August. Probably, the water flow-through and total drainage of the rearing systems led to re-suspension and release of nutrients, which are adsorbed from the sediment into the water column, and then directly into the effluent. More than $50 \%$ of the total load of most water quality variables was released in the final $20 \%$ of pond water (Boyd, 2000).

Macrophyte metabolism is, in general, associated with environmental conditions; thus, any stress factor may alter the capability of nutrient withdrawal from water (Esteves, 1998).

According to Rakocy (1999), the microorganisms in the biofilter decompose solids and inorganic nutrients essential to plant growth by means of a mineralizing process, which releases into the medium moderate amounts of essential nutrients, among them nitrogen and phosphorus.

Materials excreted in culture systems contribute to increase carbonate in the medium, for example, bicarbonate is a by-product of breathing and released by fish gills. Moreover, about $30 \%$ of fish feces contain carbon (Gowen \& Bradbury, 1987).

Alkalinity and forms of inorganic carbon changed significantly after passing through the biofilter, however their concentrations were influenced by $\mathrm{pH}$.

The different carbon types in the water are also influenced by the aquatic biota since some organisms, for example prawn, excrete ammonia and carbon dioxide as metabolites, which contribute to the presence of this element in water.
Plant metabolism uses sunlight to produce oxygen and increase $\mathrm{pH}$ during the day, while simultaneously removing ammonia and phosphate from the water (Brown \& Glenn, 1999).

Several vegetables develop better at $\mathrm{pH}$ between 5.5 and 7.0. Probably, the slightly acid to alkaline $\mathrm{pH}$ in the biofilter promoted fast growth of the plants and, therefore, filled in available space, resulting in smaller plants, mainly during April/May. Growth was faster during November/ December, which also presented higher conductivity and oxygen levels. The latter may be associated with water residence time, shorter during this period due to the high water flow required for massive organism production.

Plant total-N content was higher during July/ August, when nutrient levels in the medium were lower. On the other hand, total-P level was lower during November/December. In general, water hyacinth tended to incorporate these nutrients from the medium with differences at the beginning and end of the experiment.

Water hyacinth presented high water content and, according to Velascos et al. (1999), in general, they contain about $90 \%$ to $92 \%$ water.

At the end of the experiment (November/ December), wet and dry weight presented the highest values, indicating that during this period plants should be changed more often due to large amounts of settling material, corresponding to high fish production. During this period, it is therefore recommended that plants should be replaced every 10 days by very small buds.

Velascos et al. (1999) verified that tanks coverig with macrophyte approximately $20 \%$ of the water surface presented high levels of chlorophyll $a$ compared to tanks without macrophyte. Chlorophyll $a$ level was high over the experimental period, probably due to associated micro-fauna since phytoplankton was dominant, making up $99 \%$ of the observed total.

Micro-fauna associated with aquatic plants has a fundamental role in systemic metabolism, because when macrophytes reach the saturation point, they no longer absorb material from the medium; while associated microorganisms continue to absorb nutrients from the water column. Generally, part of the organic matter from the system can be used directly as food by associated micro and macro fauna, thus providing fast 
feedback to the trophic chain by meams of improving water quality (Boyd, 1978).

Chlorophyta was the dominant group and easily found in these systems. The abundance of phytoplankton compared to other associated microorganisms, may be related to the ease with which it is carried by the current and, also, aquatic plants function as a refuge for the planktonic community.

Among zooplankton, Rotifera, considered an opportunist species, presented the largest number of species, which might be associated with fast reproduction and adaptability to changing environmental conditions. Although Protozoa ranked second in number of species, it was dominant over two experimental periods.

During the last period (November/December), insects were dominant. Occurrence of these organisms in the biofilter may be associated with highly decomposing environmental and high phosphorus content.

Integrated system management may result in significant productive gain and environmental gains. In addition, improvement of water quality in culture ponds and tanks, especially with respect to toxic nitrogen metabolites, can be accomplished by biofilters.

The use of floating plants only, Eichhornia crassipes, in the effluent treatment was not highly effective. More research should be conducted to evaluate which plant types should be employed to achieve a satisfactory response with respect to load retention from the systems and to determine size as a function of the material load originating in the culture systems.

\section{Some recommendations for utilization of Best Management Practices (BMPs) using macrophytes biofilters in effluent}

The use of BMPs tends to improve the production and consequently decreases impact in the effluents. Thus, from obtained data some suggestions are offered to improve the biofilter efficiency of aquatic plants.

i) Boyd et al. (2000) verified that sediments are able to retain large amounts of inorganic substances in the medium. This would recommend the use of rooted plants for effluent treatments in aquaculture. ii) The appropriate management of rearing tanks and ponds would be an alternative for decreasing the nutrient load, mainly in the harvest period, thereby improving the water quality of effluents.

iii) A flow-through system, like that studied, leached large amounts of materials into the effluent, mainly from October to March (harvest). Thus, rearing tanks and ponds, rather than being completely emtied, should retain approximately $20 \mathrm{~cm}$ of water above the sediment, for 2-3 days, for pollutant sedimentation (Schwartz \& Boyd, 1996). Whatever remains should be drained for use in areas under cultivation, so avoiding so avoiding the introduction of large amounts of organic and inorganic matter directly into effluents.

iv) The size of the biofilter must be bigger than that used in the present study, and determined by the dimensions in which it is to function and residence time. According to Schwartz \& Boyd (1996), the right biofilter size, which might vary from 0.7 to 2.7 times the rearing system size and residence time ( 1 to 4 days) will result in the greatest efficiency of retention of particles in water.

v) The water that passes through the macrophyte biofilter should be reused in the rearing system, in agriculture, hydroponic culture, or even for cattle raising, since aquatic plants retain only some nutrients, while the discarded water retains a small nutrient fraction which can still be utilized.

vi) Monitoring of aquatic plants biofilter must be careful, mainly during summer, when the harvest results in high nutrient discharge and fast plant growth. During this period, withdrawal of bigger plants from biofilter must be done every 10 days, while during winter (low production period) this is required every 20 or 25 days. This management depends on the rearing system size and on water residence time relative to effluent. It is advisable to initiate a biofilter system with very small plants, which have more space for growth.

Acknowledgments - The authors wish to thank FAPESP (Fundação de Amparo à Pesquisa do Estado de São Paulo) for financial support. They are also very grateful to Silvia Regina L. de Laurentz for her invaluable help in the laboratory, Dr. Paulo Affonso Berlingieri for performing total-N and total$\mathrm{P}$ analysis, and Shogi Kikuma for aid in making the biofilter. 


\section{REFERENCES}

AOAC, 1970, Official Methods of Analysis of Association of Official Analytical Chemists. $11^{\text {th }}$ ed. Washington, 1075p.

BARAK, Y. \& RIJIN, J. V., 2000, Biological phosphate removal in a prototype recirculating aquaculture treatment system. Aquacultural Engineering, 22: 121136.

BOYD, C. E., 1978, Effluents from catfish ponds during fish harvest. J. Environ. Qual., 7: 59-62.

BOYD, C. E., 2000, Water use and conservation for inland aquaculture ponds. Fisheries Management and Ecology, 7: 55-63.

BOYD, C. E., WHITIS, G. N. \& QUEIROZ, J. F., 2000, An assessment of the environmental impact of Alabama channel catfish farming. The Catfish Journal, 10: 14-18.

BROWN, J. J. \& GLENN, E. P., 1999, Management of saline aquaculture effluent through the production of Halophyte crops. World Aquaculture, 30: 44-49.

ESTEVES, F. de A., 1998, Fundamentos de Limnologia. Editora Interciencia Ltda., Rio de Janeiro, 602p.

FOWLER, J., COHEN, L. \& JARVIS, P., 1998, Practical statistics for field biology. John Wiley \& Sons, New York, $259 \mathrm{p}$.

GIRI III, B. J. \& BOYD, C. E., 2000, Effects of effluents of frequent, small doses of calcium carbonate on water quality and phytoplankton in channel catfish ponds. North American Journal of Aquaculture, 62: 225-228.

GOLTERMAN, H. L., CLYMO, R. S. \& OHNSTAND, M. A. M., 1978, Methods for physical \& chemical analysis of fresh waters. Blackwell Sci. Publ., London, 213p.

GOWEN, R. J. \& BRADBURY, N. B., 1987, The ecological impacts of salmonid farming in coastal waters: a review. Oceanogr. Mar. Biol. Ann. Rev., 25: 563-575.
KOROLEFF, F., 1976, Determination of nutrients. In: K. Grassnof (ed.), Methods of sea water analysis, Verlag Cemie. Weinhein., New York.

MACKERETH, F. J. H., HERON, J. \& TALLING, J. F., 1978 Water analysis: some revised methods for limnologists. Freshwater Biological Association Scientific Publication n. 36, Titus Wilson \& Sons Ltda, London, 121p.

NUSH, E. A., 1980, Comparison of different methods for chlorophyll and phaeopigments determination. Archiv. fuer Hydrobiologie, 14: 14-36.

RAKOCY, J., 1999, Aquaculture engineering: the status of aquaponics, Part 1. Aquaculture Magazine, 25: 82-88.

SARRUGE, J. R. \& HAAG, H. P., 1974, Análise química em plantas. ESALQ/USP, Piracicaba, SP, 56p.

SCHWARTZ, M. F. \& BOYD, C. E., 1996, Suggested management to improve quality and reduce quantity of channel catfish pond effluents. Alabama Agricultural Experiment Station Auburn Univesity, 3: 1-4.

SIEGEL, S., 1975, Estatística não-paramétrica (para as ciências do comportamento). Ed. McGraw-Hill do Brasil, São Paulo, 349p.

SILVA, S. da \& ANDERSON, T. A., 1995, Fish nutrition in aquaculture. Chapman \& Hall, London, 319p.

SOKAL, R. R. \& ROHLF, F. J., 1981, Biometry. The principles and practice of statistics in biological research. W. $\mathrm{H}$ Freeman and Company, San Francisco, 857p.

SUMMERFELT, S. T., HANKINS, J. A., WEBER, A. L. \& DURANT, M. D., 1997, Ozonation of a recirculating rainbow trout culture systems. II Effects on microscreen filtration and water quality. Aquaculture, 158: 57-67.

VELASCO, M., SALAME, M. \& CORTES, R., 1999, Water hyacinths in tilapia ponds: a preliminary study. Aquaculture Magazine, 25: 46-55. 